\title{
Socialt rum og symbolsk magt
}

\author{
Pierre Bourdieu (1930-2003) \\ Professor i Sosiologi, Collège de France
}

Jeg vil, inden for rammerne af en forelæsning, fors $\varnothing$ ge at præsentere de teoretiske principper, som ligger bag den unders $\emptyset$ gelse, hvis resultater præsenteres i La Distinction (Bourdieu, 1979), og trække visse af de teoretiske implikationer frem, som med st $\varnothing$ rst sandsynlighed vil forvirre læseren, især her i USA på grund af forskellene i vore kulturelle traditioner. Hvis jeg skulle karakterisere mit arbejde i få ord, dvs., som det så ofte gøres nu om dage, sætte en etiket på det, vil jeg tale om konstruktivistisk strukturalisme eller om strukturalistisk konstruktivisme, hvor ordet strukturalist skal tages i en ganske anden betydning end i Ferdinand de Saussures eller Claude Levi-Strauss'tradition. Med

strukturalisme eller strukturalist mener jeg, at der i selve den sociale verden, og ikke kun i symbolske systemer, såsom sprog, myter etc., eksisterer objektive strukturer, som er uafhængige af agenternes bevidsthed og $\emptyset$ nsker og er i stand til at lede eller tvinge deres praktikker eller deres repræsentationer. Med konstruktivisme mener jeg, at der finder en social genese sted: På den ene side af de opfattelses-, tænke- og handlemønstre, som konstituerer det jeg kalder habitus, og på den anden side af de sociale strukturer, og i særdeleshed af det, jeg kalder felter og grupper, og som almindeligvis kaldes sociale klasser.

(Jeg mener, at det her er specielt vigtigt at gøre dette helt klart: Oversættelsernes tilfældigheder gør, at f.eks. La Reproduction (Bourdieu \& Passeron, 1970) er velkendt her, hvilket får bestemte kommentatorer - og visse af dem har ikke tøvet med det - til at klassificere mig som strukturalist, mens arbejder, som stammer fra en meget tidligere periode, er ukendte. De er så gamle, at de oven i købet foregriber de typisk 'konstruktivistiske' arbejder om de samme emner. Disse arbejder ville uden tvivl gøre, at jeg ville blive opfattet som 'konstruktivist': Således viste vi i en bog kaldet Rapport pédagogique et communication (Bourdieu, Passeron, de Saint Martin red., 1965), hvordan en social erkendelses-relation konstrueres i og ved misforståelse, eller på trods af misforståelse; hvordan lærere og studenter efter en art tavs forhandling, tavst ledet af behovet for at minimere omkostninger og risici, bliver enige om at acceptere en minimal definition af kommunikationssituationen. På samme måde fors $\varnothing$ ger vi i en anden unders $\varnothing$ gelse kaldet "The Categories of Professorial Judgement" (Bourdieu, 1988) at analysere genesen og funktionen af de opfattelses- og vurderingskategorier, gennem hvilke lærere opfatter deres elever, deres præstationer og værdi, og

Teksten er oversatt av Karin Anna Petersen og Morten Nørholm. Teksten er en oversættelse af Bourdieu (1990). Oversættelsen er tidligere publiceret i Callewaert et al. (Red.)(1994-2008, s. 52-69). Oversætterne takker Frydenlund for tilladelsen til at bringe teksten her.

Publisert: 28.06.2019

Praxeologi - Et kritisk refleksivt blikk på sosiale praktikker (C2019 Pierre Bourdieu

DOI: http://dx.doi.org/10.15845/praxeologi.v1i0.2548 
ved hjælp af selvsupplering, vejledt af de samme kategorier, producerer deres egen gruppe, nemlig den, der består af deres kolleger og derved lærerkollegiet. Nu, da denne korte parentes er af vejen, kan jeg vende tilbage til mit overordnede emne).

Taler man i meget generelle termer, svinger socialvidenskaben, i antropologi såvel som i sociologi og historie, mellem to tilsyneladende uforenelige synspunkter, to tilsyneladende modstridende perspektiver: Objektivisme og subjektivisme, eller hvis man foretrækker det, fysikalisme og psykologisme (som kan tones forskelligt, fænomenologisk, semiologisk etc.). På den ene side kan socialvidenskab "behandle sociale fænomener som ting", i overensstemmelse med den gamle durkheimske maksime, og således udelade alt det, der tilskrives det faktum, at de er objekter for erkendelse - eller miskendelse - med social eksistens. På den anden side kan socialvidenskab reducere den sociale verden til den repræsentation, agenterne skaber af den, således at socialvidenskabens opgave er at producere et "resultat af resultaterne" produceret af sociale subjekter.

Det er sjældent at disse to positioner udtrykkes, og endnu mere at de realiseres i videnskabelig praksis, på så radikal og kontrasterende en måde. I ved, at Émile Durkheim uden tvivl, sammen med Karl Marx, er den person som har udtrykt den objektivistiske position mest konsistent: "Vi mener, at ideen om, at det sociale liv skal forklares, ikke ud fra agenternes tanker, men af de dybe årsager, der ligger uden for bevidstheden, er frugtbar." Men som en god kantianer var han ikke uvidende om, at denne virkelighed ikke kan begribes uden at bringe logiske instrumenter i arbejde. Når dette er sagt: Objektivistisk fysikalisme associeres ofte med den positivistiske hang til at forestille sig klassifikationer som 'operative' måder at skære ting op eller som mekaniske registreringer af 'objektive' brud og diskontinuiteter (f.eks. i statistiske fordelinger). Det er uden tvivl hos Alfred Schutz og etnometodologerne, at man kan finde de reneste udtryk for den subjektivistiske vision. Således indtager Schutz nøjagtig det modsatte standpunkt af Durkheims:

Socialvidenskabsmandens observationsfelt, den sociale virkelighed, har en særlig mening og passende struktur, relevant for de mennesker, som lever, handler og tænker i den. Ved en serie af sund fornuftkonstruktioner har de forud valgt og oversat den verden, som de opfatter som deres dagliglivs virkelighed. Det er disse tankeobjekter, som determinerer deres adfærd ved at motivere den. Tankeobjekterne, konstrueret af socialvidenskabsmanden med det formål at begribe denne sociale virkelighed, skal baseres på de tankeobjekter, som er konstrueret af sund fornufts-tænkningen af de mennesker, som lever deres daglige liv i deres sociale verden. Således er socialvidenskabernes konstruktioner, så at sige, andengrads konstruktioner, dvs., konstruktioner af konstruktionerne, udført af aktørerne på den sociale scene (Schutz, 1973).

Modsætningen er total: I det ene tilfælde kan videnskabelig viden udelukkende opnås ved at bryde væk fra de primære repræsentationer - kaldet forudantagelser hos Durkheim og ideologi hos Marx; dette brud fører til antagelsen af ubevidste årsager. I det andet tilfælde ligger videnskabelig viden i forlængelse af sund-fornufts viden, fordi det kun er en "konstruktion af konstruktioner".

Hvis det virker, som om jeg har arbejdet lidt vel rigeligt med denne modsætning, et af de mest uheldige af de begrebspar, der, som Reinhard Bendix og Bennett M. Berger har vist det, florerer i de sociale videnskaber, er det fordi den mest konstante, og i mine øjne den vigtigste, intention med mit arbejde har været at overskride modsætningen. Med fare for at virke meget uklar vil jeg forsøge at opsummere hele den analyse jeg sigter mod i dag, i en sætning: På den ene side: De objektive strukturer, som sociologen konstruerer ved at tilsidesætte agenternes subjektive repræsentationer $\mathrm{i}$ det objektivistiske moment; de er basis for de subjektive repræsentationer, og de konstituerer den strukturelle tvang som påvirker interaktioner. Men på den anden side: Disse repræsentationer skal også huskes, når man fremfor alt vil tage højde for de daglige individuelle og kollektive kampe, der har til formål at forandre eller bevare disse strukturer. Dette betyder, at de to momenter, det 
objektivistiske og det subjektivistiske, står i et dialektisk forhold, og selvom f.eks. det subjektivistiske, hvis det tages isoleret, synes meget tæt på interaktionistiske eller etnometodologiske analyser, er det adskilt fra dem med en radikal forskel: Udgangspunkterne opfattes som sådan og relateres til positionerne i de korresponderende agenters struktur.

For fuldt ud at overskride den kunstige modsætning, der tenderer mod at opstå mellem strukturerne og repræsentationer, må man også bryde med den tankemåde, som Ernst Cassirer kalder substantialistisk, og som forleder folk til ikke at anerkende nogen virkeligheder udover dem, der er tilgængelige for direkte intuition i almindelig erfaring, hos individer og grupper. Det største bidrag til det, man må kalde den strukturalistiske revolution, bestod i at tilføje den sociale verden en relationel tankemåde, som er den samme som i moderne fysik og matematik, og som identificerer det virkelige ikke med substanser, men med relationer. Den "sociale virkelighed", som Durkheim talte om, er et sæt af usynlige relationer, de selvsamme relationer som konstituerer et rum af positioner, udvendige i forhold til hinanden og defineret ved deres nærhed til, naboskab med eller afstand fra hinanden, og også ved deres relative position - over eller under, eller endog imellem, i midten. Sociologi, i dets objektivistiske moment, er en social topologi, en analysis situs, som denne nye gren af matematikken blev kaldt på Gottfried W. Leibniz' tid, en analyse af relative positioner og objektive relationer mellem disse positioner.

Denne relationelle tænkemåde er udgangspunktet for konstruktionen, som er præsenteret i La Distinction. Men det er rimeligt at mene, at rummet, dvs. relationerne, vil være ubemærkede af læserne, på trods af brugen af diagrammer (og af korrespondanceanalysen, som er en meget sofistikeret form for faktoranalyse): På den ene side fordi den substantialistiske tænkemåde er lettere, mere 'naturlig'; på den anden side fordi, som det ofte er tilfældet, de midler, man er nødt til at benytte for at konstruere det sociale rum og for at kunne manifestere dette, risikerer at skjule de resultater, midlerne gør én i stand til at opnå. De grupper, man skal konstruere for at kunne objektivere de positioner de optager, skjuler disse positioner, og kapitlet i La Distinction om fraktioner af den dominante klasse læses som en beskrivelse af disse fraktioners forskellige livsstile, i stedet for at blive læst som en analyse af måden, hvorpå de skal ses som positioner i rummet af magtpositioner - det som jeg kalder magtfeltet. (I parentes vil jeg bemærke, at ændringen i ordvalg, som I kan se, både er betingelsen for og resultatet af at bryde med de ordinære repræsentationer, som er associeret med ideen om en herskende klasse.)

Man kan på dette sted i diskussionen sammenligne det sociale rum med et geografisk rum, som er delt op i regioner. Men dette rum er konstrueret således, at agenterne, grupperne eller institutionerne, som finder sig selv situeret i det, har flere egenskaber til fælles, desto tættere de er på hinanden i dette rum; og færre fælles egenskaber desto fjernere de er fra hinanden. Rumlige afstande - på papir - falder sammen med sociale afstande. Det samme er ikke tilfældet i et virkeligt rum: Det er sandt, at man næsten overalt kan observere en tendens til isolation; folk, der er tæt på hinanden i det sociale rum tenderer - af valg eller nødvendighed - mod at være tæt på hinanden i det geografiske rum; imidlertid kan folk, som er meget fjerne fra hinanden i det sociale rum støde på hinanden, påvirke hinanden, i det mindste kortvarigt og forbigående, i det fysiske rum. Interaktioner, der tages for pålydende af folk med en empiricistisk disposition - idet man kan observere dem, filme dem, registrere dem, kort sagt de er håndgribelige - skjuler de strukturer, som realiseres i dem. Det er et af de tilfælde, hvor det synlige, det som er umiddelbart givet, skjuler det usynlige, som determinerer det. Man glemmer derfor, at interaktionens sandhed aldrig fuldstændigt kan findes tilgængelig i interaktionen, som den er tilgængelig for observation. Ét eksempel er tilstrækkeligt. til at vise forskellen mellem struktur og interaktion og, på samme tid, mellem den strukturalistiske vision, som jeg vil forsvare som et $n \varnothing d v e n d i g t$ forsknings-moment, og den såkaldte interaktionist-vision $i$ alle dens udtryksformer (i særdeleshed etnometodologi). Jeg tænker på det, som jeg kalder strategierne for at nedlade sig. Agenter, der optager en højere position i et af det objektive rums hierarkier, 
benægter symbolsk den sociale distance. Den ophører hermed ikke med at eksistere, men de højtstillede håber det sikrer dem de anerkendelsens fordele, som er knyttet til en rent symbolsk benægtelse af distance ("han er upåvirket", "han gør sig ikke til" etc.). Den symbolske benægtelse implicerer imidlertid en anerkendelse af en distance (de sætninger jeg har citeret har altid implicit en fortsættelse: "Han er upåvirket, af at være hertug", "han gør sig ikke til af at være universitetsprofessor" etc.). Kort sagt, man kan bruge de objektive distancer til at opnå fordelene ved nærhed og fordelene ved distance, dvs. den distance og den anerkendelse af distance, som er sikret ved den symbolske negation af distance.

Hvordan kan man således konkret begribe disse objektive relationer, som ikke kan reduceres til de interaktioner inden for hvilke de manifesteres? Disse objektive relationer er relationer mellem positionerne, som er besat i fordelingen af ressourcer, som er eller vil blive aktive, effektive, som trumferne i et spil kort, i konkurrencen om tilegnelsen af de sjældne goder, som dette sociale univers er locus for. I overensstemmelse med mine empiriske unders $\emptyset$ gelser er disse fundamentale sociale kræfter, økonomisk kapital i dens forskellige former, kulturel kapital og også symbolsk kapital, som er en form, der antages af forskellige slags kapital, hvis de opfattes og anerkendes som legitime. Derfor er agenterne fordelt i det totale sociale rum, i den første dimension i overensstemmelse med det totale omfang af den kapital de besidder i forskellige former, $i$ den anden dimension $i$ overensstemmelse med strukturen af deres kapital, dvs. i overensstemmelse med den relative vægt de forskellige slags kapitaler, økonomiske og kulturelle, har af den totale kapital.

De misforståede læsninger af analyserne, som jeg har udført især i La Distinction, stammer derfor fra det faktum, at klasser på papir risikerer at blive opfattet som reale grupper. Denne realistiske læsning bliver objektivt understøttet af det faktum, at det sociale rum er konstrueret på en sådan måde, at agenter, som optager samme eller lignende positioner, er placeret i ensartede forhold og underkastet ensartede betingelser, og har alle chancer for at have ensartede dispositioner og interesser, og således for at producere praktikker som endda er ensartede. De dispositioner, som er opnået i de besatte positioner, implicerer en tilpasning til denne position, som Erving Goffmann kaldte for "fornemmelsen for ens placering". Det er denne fornemmelse for ens placering, som får folk - på fransk kaldet 'les gens modestes', dvs. 'almindelige mennesker' - til i interaktioner at holde sig til deres 'almindelige' sted og de andre til at 'holde afstand' eller 'respektere deres rang' og 'ikke blive fortrolige'. Disse strategier kan imidlertid være helt ubevidste og kan antage former som generthed eller arrogance. Faktisk er sociale afstande indskrevet i kroppene eller, mere præcist, i forholdene til kroppen, til sprog og til tid. (Dette er så mange af de strukturelle aspekter af praktikken, som ignoreres af den subjektivistiske vision).

Hvis man til dette lægger, at fornemmelsen for ens placering, og habitus' affiniteter erfaret som sympati eller antipati, er grundlag for alle former for samarbejde, venskaber, kærlighedsaffærer, giftermål, forbindelser etc., altså for alle de forhold, som er langvarige og somme tider sanktioneret ved lov, så vil man se, at alt fører én til at tro, at klasser på papir er reale grupper - endog mere reale, eftersom rummet er bedre konstrueret, og enhederne, i hvilke dette rum er underinddelt, er mindre. Hvis man vil grundlægge en politisk bevægelse eller ligefrem en forening, vil man have en bedre chance for at bringe folk sammen som befinder sig i den samme sektor af rummet (f.eks. i det nordvestlige af diagrammet, der hvor de intellektuelle er) end hvis man vil bringe de folk sammen, som er i regionerne i de fire hjørner af diagrammet.

Men ligesom subjektivismen får folk til at reducere strukturer til interaktioner, tenderer objektivismen mod at udlede aktion og interaktion fra strukturen. Så hovedfejlen, fejlen ved teoretiseringen, som man finder hos Marx, ser ud til at bestå i at behandle klasser på papir som reale klasser ved at konkludere fra betingelsers og påvirkningers objektive homogenitet og således fra dispositioner, som alle stammer fra identiteten af positionen i det sociale rum, til at de involverede mennesker eksisterer som en forenet gruppe, som en klasse. Opfattelsen af socialt rum tillader en at 
gå bagom alternativet nominalisme eller realisme, når det kommer til sociale klasser: Det politiske foretagende, som havde til hensigt at producere sociale klasser som 'samarbejdende enheder ', permanente grupper, udrustet med permanerfre repræsentationsorganer, forkortelser etc., har så meget desto st $\varnothing$ rre chance for succes, fordi de agenter, som det $\emptyset$ nsker at bringe sammen, forene og konstituere som en gruppe, er tættere i det sociale rum (og tilhører således den samme klasse på papiret). Klasser i Marx' forståelse skal produceres af et politisk foretagende, som har så meget desto større chance for succes, i og med at det understøttes af en teori, som er velfunderet i virkeligheden, og som derfor er i stand til at udføre en teorieffekt - theorein på græsk betyder at se - der med andre ord er i stand til at påtvinge en vision om opdelingen.

Med teorieffekten har vi forladt den rene fysikalisme, men uden at opgive den erfaring, som er opnået i den objektivistiske fase: Grupper - sociale klasser - skal skabes. De er ikke givet i den "sociale virkelighed". Titlen på den berømte bog af E. P. Thompson, The Making af the English Working Class (Thompson, 1963), skal tages bogstaveligt: Arbejderklassen, som den fremstår for os i dag, via de ord som skal betegne den (arbejderklasse, proletariat, arbejdere, arbejderbevægelser etc.), og med de organisationer, som skal udtrykke den (de forkortede navne, kontorerne, sekretariaterne og flagene etc.), er en velfunderet historisk artefakt (forstået sådan som Durkheim formulerede det: At religionen er en velfunderet illusion). Men det betyder ikke, at man blot kan konstruere hvad som helst, på hvilken som helst måde, hverken i teorien eller i praksis. Vi har således bevæget os fra social fysik til social fænomenologi. Den "sociale virkelighed", som objektivisterne taler om, er derpå et objekt for perception. Socialvidenskaben må nødvendigvis som sit objekt tage både denne virkelighed og opfattelsen af denne virkelighed, perspektiverne, synspunkterne, som agenterne har om denne virkelighed, i kraft af deres position i det objektive sociale rum. De spontane visioner om den sociale verden ("folketeorierne", som etnometodologerne taler om, eller det, jeg kalder spontan sociologi), men også videnskabelige teorier og sociologien er dele af den sociale virkelighed og kan, som f.eks. den marxistiske teori, opnå en i det hele taget virkelig, konstruerende magt.

Det objektivistiske brud med forudopfattelser, ideologier, spontan sociologi, og "folketeorier", er et uundgåeligt og $n \emptyset$ dvendigt moment i den videnskabelige procedure. Man kan ikke undgå det uden at udsætte sig selv for alvorlige fejltagelser (som interaktionisme, etnometodologi og alle former for socialpsykologi, der stiller sig tilfredse med en fænomenologisk vision om den sociale verden). Men man må udføre et andet og mere vanskeligt brud med objektivismen ved, $i$ et andet trin, at reintroducere det, det var nødvendigt at udelukke for at konstruere den sociale virkelighed.

Sociologi skal indeholde en sociologi om opfattelsen af den sociale verden, dvs. en sociologi om konstruktionen af de verdenssyn, som selv bidrager til konstruktionen af denne verden. Men givet det faktum, at vi har konstrueret et socialt rum, ved vi, at disse synspunkter, som det ligger i ordet selv, er syn, der går fra et bestemt punkt, dvs. fra en given position inden for det sociale rum. Vi ved også, at der vil være forskellige eller ligefrem modsatte synspunkter, fordi synspunkter er afhængige af fra hvilket punkt der ses. Den vision, enhver agent har om rummet, er afhængig af hans eller hendes position i det pågældende rum.

Ved at gøre dette, nægter vi at anerkende det universelle subjekt, fænomenologiens transcendentale ego, som etnometodologerne har overtaget som deres eget. Agenterne har uden tvivl en aktiv forståelse af verden. Uden tvivl konstruerer de deres vision om verden. Men denne konstruktion udføres under strukturel tvang. I sociologiske termer kan man ovenikøbet forklare, hvad der forekommer som en universel egenskab ved menneskelig erfaring, men som i den velkendte verden tenderer mod at blive 'taget for givet', opfattet som naturlig. Hvis den sociale verden tenderer mod at blive opfattet som indlysende og som begribelig med en doxisk modalitet, for at bruge Edmund Husserls termer, er det fordi agenternes dispositioner, deres habitus, dvs. de mentale strukturer, gennem hvilke de forstår den sociale verden, essentielt er produktet af en internalisering af strukturerne i den sociale verden. Ligesom dispositioner i forbindelse med opfattelse af 
omgivelserne tenderer mod at blive tilpasset til positionen, vil selv de mest forfordelte agenter tendere mod at opfatte verden som naturlig og at finde den meget mere acceptabel end man skulle forestille sig, især hvis man ser de domineredes situation med de dominerendes sociale øjne.

At lede efter de invariante former for perception eller konstruktionen af social virkelighed tilslører altså forskellige ting: For det første det faktum, at denne konstruktion ikke udføres i et socialt vakuum, men at den er underkastet strukturel tvang; for det andet, at de strukturerende strukturer, de kognitive strukturer, selv er socialt struktureret, fordi de er af social oprindelse; for det tredje, konstruktionen af social virkelighed er ikke kun en individuel opgave, men kan også blive en kollektiv opgave. Men den såkaldt mikro-sociologiske vision udelader en hel del andre ting: Som det ofte sker, når man ser nærmere efter, kan man ikke se skoven for bare træer; og fremfor alt, fordi man ikke har konstrueret rummet, har man ingen chance for at se det punkt, hvorfra man kan se, hvad man ser.

Derfor varierer agenternes repræsentation med deres position (og de tilhørende interesser) og med deres habitus, som et system af opfattelses- og vurderings-modeller, som kognitive og evalueringsmæssige strukturer, der er opnået gennem en langvarig erfaring med en social position. Habitus er på samme tid et system af modeller til produktion af praktikker og et system af modeller til opfattelse og vurdering af praktikker. I begge tilfælde udtrykker dens operationer den sociale position, i hvilken den er konstrueret. Som et resultat producerer habitus praktikker og repræsentationer, som er tilgængelige for klassifikation, som er objektivt differentierede; men umiddelbart opfattes de som sådanne udelukkende i det tilfælde, hvor agenterne besidder koden, de klassifikatoriske modeller, som er nødvendige for at forstå deres sociale mening. På denne måde implicerer habitus en 'fornemmelse for ens egen placering' men også en 'fornemmelse for den andens placering'. Vi siger for eksempel om et stykke tøj, et møbel eller en bog: 'Den er småborgerlig' eller' den er intellektuel'. Hvad er de sociale betingelser for en sådan bedømmelse? For det første forudsætter den, at smag (eller habitus), som et system af klassifikatoriske modeller, objektivt, gennem de sociale betingelser som producerede den, henviser til et socialt vilkår: Agenterne klassificerer sig selv, udsætter sig selv for klassifikation, ved, i overensstemmelse med deres smag, at vælge forskellige attributter, tøj, typer af mad, drikke, sportsgrene, venner, som går godt sammen og som de også synes de stemmer overens med, eller mere præcist, som de synes er passende for deres position. Mere præcist: De klassificerer sig selv i rummet med tilgængelige varer og tjenesteydelser ved at vælge ting, som optager en plads i dette rum overensstemmende med positionen, de optager $i$ det sociale rum. Det betyder, at intet klassificerer nogen bedre end den måde, hvorpå han eller hun klassificerer.

For det andet forudsætter en klassifikatorisk bedømmelse, såsom 'det er småborgerligt', at vi som socialiserede agenter er i stand til at se relationen mellem praktikker eller repræsentationer og positioner i det sociale rum (som når vi kan gætte en persons sociale position ud fra hans eller hendes accent). På denne måde har vi, via habitus, en verden af sund fornuft, en social verden, som synes at være indlysende.

Jeg har indtil nu antaget det opfattende subjekts position og har nævnt den vigtigste faktor $\mathrm{i}$ variationerne af opfattelse, nemlig positionen i det sociale rum. Men hvad med variationer, hvis oprindelse snarere er på objektets niveau, på selve dette rums niveau? Det er sandt, at den overensstemmelse, der gennem habitus, disposition og smag etableres mellem positioner og praktikker, demonstrerede præferencer, udtrykte holdninger etc., betyder, at den sociale verden ikke præsenterer sig som totalt kaos, fuldstændig blottet for $n \varnothing d v e n d i g h e d$ og i stand til at blive konstrueret på hvilken som helst måde. Men denne verden præsenterer heller ikke sig selv som fuldstændigt struktureret, eller som værende i stand til at påtvinge ethvert opfattende subjekt principperne for sin egen konstruktion. Den sociale verden kan beskrives og konstrueres på forskellige måder i overensstemmelse med forskellige principper for vision og division - for eksempel $\varnothing$ konomiske inddelinger og etniske inddelinger. Hvis det er sandt, at $\varnothing$ konomiske og kulturelle 
faktorer har størst indflydelse på differentieringen i de samfund, som er mest avancerede ud fra et $\varnothing$ konomisk synspunkt, er det faktum tilbage, at styrken af $\varnothing$ konomiske og sociale forskelle aldrig er således, at man ikke kan organisere agenterne ved hjælp af andre inddelingsprincipper - f.eks. etniske, religiøse eller nationale.

På trods af denne potentielle mangfoldighed af mulige struktureringer - hvad Max Weber kaldte die Vielseitigkeit af det givne - er det ikke desto mindre sandt, at den sociale verden selv præsenterer sig som en stærkt struktureret virkelighed. Det er på grund af en simpel mekanisme, som jeg hurtigt vil skitsere. Det sociale rum, som jeg har beskrevet det ovenfor, præsenterer sig som agenter udstyret med forskellige egenskaber, der er systematisk sammenkædet: De mennesker, der drikker champagne, er modstillet dem, der drikker whisky, men de er også på en anden måde modstillet dem, der drikker rødvin; men de, der drikker champagne, er mere tilbøjelige end dem, der drikker whisky, og meget mere tilbøjelige end dem, der drikker rødvin, til at have antikke møbler, spille golf, ride eller til at gå $i$ teatret for at se lette komedier. Disse egenskaber fungerer som tegn i det sociale livs virkelighed, når de opfattes af agenter udstyret med relevante opfattelseskategorier (i stand til at se, at det at spille golf får en til at 'ligne' et traditionelt medlem af den $\varnothing$ vre middelklasse): Forskellene fungerer enten positivt eller negativt som skelsættende tegn og som tegn på skel, og dette sker uden nogen intention om denne skelnen, uden noget $\emptyset$ nske om iøjnefaldende forbrug. Det skal i $\emptyset$ vrigt siges, at mine analyser intet tilfælles har med Oswald Veblens: Dette er så meget desto mere sandt, som at skelnen, set ud fra oprindelige kriterier, udelukker ethvert ønske om skelnen. Med andre ord præsenterer den sociale verden sig objektivt via den fordeling af egenskaber som et symbolsk system, der er organiseret i overensstemmelse med logikken om forskel, om differentieret variation. Det sociale rum tenderer mod at fungere som et symbolsk rum, et rum med livsstile og statusgrupper, karakteriseret ved forskellige livsstile.

På denne måde er opfattelsen af den sociale verden et produkt af en dobbelt strukturering: På det objektive niveau er den socialt struktureret, fordi egenskaberne knyttet til agenterne eller institutionerne præsenterer sig selv i kombinationer, som har meget ulige sandsynligheder: Ligesom det er mere almindeligt, at fjerede dyr har vinger end at pelsede dyr har det, er indehaverne af en sofistikeret bemestring af sprog mere sandsynlige på et museum end dem, der ikke har denne bemestring. På det subjektive niveau er opfattelsen af den sociale verden struktureret, fordi de opfattelses- og evalueringsmæssige modeller, især de nedskrevne, udtrykker tilstanden for den symbolske magts relationer. Jeg tænker eksempelvis på de adjektivpar (tung/let, strålende/dunkel etc.), som strukturerer smag på de mest forskellige domæner. Disse to mekanismer handler sammen for at producere en fælles verden, en verden af sund fornuft eller, i det mindste, en minimumsenighed om den sociale verden.

Men som jeg har foreslået det, kan objekterne i den sociale verden opfattes og udtrykkes på forskellige måder, fordi de altid inkluderer en grad af ubestemthed og uklarhed og dermed en vis grad af semantisk elasticitet: Kombinationer af de mest konstante egenskaber er altid baseret på statistiske sammenhænge mellem udskiftelige karakteristika; og ydermere er de underkastet variationer over tid, så deres mening, for så vidt som de er afhængige af fremtiden, selv er holdt i uvished og relativt ubestemte. Dette objektive element af usikkerhed - som ofte er forstærket af kategoriseringseffekten, idet det samme ord kan dække forskellige praktikker - tilbyder et grundlag for en mangfoldighed af verdenssyn, som selv er kædet sammen med en mangfoldighed af synspunkter. På samme tid tilbyder det objektive element et grundlag for symbolske kampe om magten til at producere og påtvinge en vision om den legitime verden. (Det er i midterpositionerne i det sociale rum, især i De forenede Stater, at ubestemtheden og den objektive usikkerhed om forholdene mellem praktikker og positioner er på deres højeste; og som en konsekvens er også intensiteten af kampen mellem de symbolske strategier skruet op. Det er let at forstå, at det er dette univers som udgør interaktionisternes priviligerede terræn, og især Goffmans.) 
Symbolske kampe om opfattelsen af den sociale verden kan antage to forskellige former. På det objektive plan kan man pege på repræsentations-handlinger, individuelle eller kollektive, beregnet til at afsløre og vigte sig af bestemte realiteter. Kollektivt tænker jeg for eksempel på demonstrationer, hvis formål er at pointere en gruppe, dens størrelse, dens styrke, dens sammenhængskraft, at synliggøre dens eksistens; og på det individuelle plan tænker jeg på alle selv-præsentationsstrategierne, som er så velanalyserede af Goffman, designet til at manipulere ens selvopfattelse og især - hvad Goffman udelod - opfattelsen af ens position i det sociale rum. På det subjektive plan må man handle ved at forsøge at ændre opfattelses- og evalueringskategorierne i den sociale verden, de kognitive og evalueringsmæssige strukturer. Opfattelseskategorierne, klassifikationssystemerne, det vil hovedsageligt sige ordene, navnene, der konstruerer den sociale virkelighed lige så meget, som de udtrykker den, er den afgørende indsats i den politiske kamp. Den politiske kamp er en kamp for at påtvinge de legitime principper for vision og division - ergo en kamp for den legitime udøvelse af teorieffekten. Jeg har vist med tilfældet Kabylien, at grupper, husholdninger, klaner, stammer og navnene, der betegner dem, er instrumenter og objekter for utallige strategier, og at agenterne uafladeligt er beskæftiget med forhandlinger om deres egen identitet: For eksempel kan de manipulere med stamtavler ligesom vi, og af andre årsager, manipulerer med lærebøgerne af de fædre, som har grundlagt disciplinen. På niveau med den daglige klassekamp, som de sociale agenter gennemfører i en isoleret og splittet tilstand, er strategierne ligeledes fornærmelser, såsom magiske fors $\varnothing \mathrm{g}$ på kategorisering: Sladder, rygter, bagvaskelser, insinuationer, etc. På det kollektive og mere egentligt politiske niveau inkluderer de alle strategierne, som sigter mod at påtvinge en ny konstruktion af den sociale virkelighed ved at afvise det gamle politiske ordforråd, men ellers sigter mod at opretholde det ortodokse syn ved at bevare de ord, som oftest er eufemismer (lige nu refererede jeg til udtrykket 'almindelige mennesker'), udformet til at beskrive den sociale verden. De mest typiske af disse konstruktionsstrategier er dem, der sigter mod retrospektivt at rekonstruere en fortid, tilpasset til nutidens behov - som da general Flemming, da han landede i Frankrig i 1917, sagde: "La Fayette, here we come!" - men ellers sigter mod at konstruere fremtiden, gennem en kreativ forudsigelse, bestemt til at begrænse den evigt-åbne betydning af nutiden.

Disse symbolske kampe, både de individuelle dagligdags kampe og de kollektive, organiserede kampe i det politiske liv, har en specifik logik, som sikrer dem en reel autonomi fra de strukturer, i hvilke de har rod. I kraft af det faktum, at den symbolske kapital ikke er andet end økonomisk eller kulturel kapital, som dog er erkendt og anerkendt, idet den ses i overensstemmelse med de opfattelseskategorier, den selv påtvinger, tenderer den symbolske kapital mod at reproducere og forstærke de magtrelationer, som konstituerer strukturen i det sociale rum. Mere konkret: Legitimeringen af den sociale orden er ikke, som bestemte folk tror, et produkt af en velovervejet forudindtaget propagandaaktion eller symbolsk påtvingning; den skyldes det faktum, at agenter tilføjer den sociale verdens objektive strukturer opfattelses- og vurderingsstrukturer, som er opstået af disse objektive strukturer og derfor vil forstå verden som selv-indlysende.

Objektive magtrelationer tenderer mod at reproducere sig i symbolske magtrelationer. I den symbolske kamp om produktionen af sund fornuft eller, mere præcist, om monopolet for legitim navngivning sætter agenter den symbolske kapital, som de har opnået i tidligere kampe og som juridisk kan garanteres, i kraft. På denne måde repræsenterer adelstitler, ligesom uddannelsesmæssige kvalifikationer, reelle titler med symbolsk egenskab, som giver én retten til fordelene ved anerkendelsen. Også her bliver man nødt til at flytte sig fra marginalistisk subjektivisme: Den symbolske orden er ikke konstitueret som en markedspris ved den blotte mekaniske addition af de individuelle ordener. På den ene side har ikke alle bedømmelser den samme vægt ved fastsættelsen af den objektive klassifikation og hierarkiet af værdier tildelt individer og grupper; og de personer, der har en stor symbolsk kapital, eksempelvis adelen, dvs. etymologisk set dem, der er erkendt og anerkendt, er i en position, hvor de kan påtvinge den værdiskala, som er 
mest favorabel for deres produkter. Det kan de især, fordi de i vore samfund har et de facto monopol på institutioner, der ligesom uddannelsessystemet officielt etablerer og garanterer rang. På den anden side må symbolsk kapital officielt sanktioneres, garanteres og etableres juridisk ved en officiel udnævnelse. Officiel udnævnelse, med andre ord den handling, hvor man tildeler nogen en titel for en socialt anerkendt kvalifikation, er en af de mest typiske demonstrationer af det monopol på legitim symbolsk vold, som tilhører staten eller dens repræsentanter. Et diplom eller et eksamensbevis er en universelt anerkendt og garanteret symbolsk kapital, der er gyldigt på alle markeder. Som en officiel definition på en officiel identitet frig $\varnothing r$ det indehaveren fra den symbolske 'alles kamp mod alle' ved at påtvinge det universelt anerkendte perspektiv.

Staten, som producerer den officielle klassifikation, er i en vis forstand den højeste domstol, som Franz Kafka refererer til i Processen, når Block siger om en af advokaterne, der påstår at være en af de 'store advokater': "Enhver kan naturligvis kalde sig selv 'stor', hvis han har lyst, men i denne sag må retstraditionen afgøre det." (Kafka, 1953, s.197). Videnskaben behøver ikke at vælge mellem relativisme og absolutisme: Sandheden om den sociale verden står på spil i (kampene mellem agenter, som er ulige udstyret til at nå en absolut, dvs. en selvbekræftende, vision: Set i perspektiv tildeler legaliseringen af symbolsk kapital en absolut, universel værdi, som på denne måde frigør den fra en relativitet, der per defimtion er uadskillelig fra ethvert synspunkt, forstået som et syn set fra et bestemt punkt i det sociale rum.

Der er et officielt synspunkt, som er de officielles synspunkt og som udtrykkes i officiel diskurs. Denne diskurs, som Aaron V. Cicourel har vist det, opfylder tre funktioner: For det første udfører den en diagnostik, dvs. en erkendelseshandling, som forstærker anerkendelse, og som ganske ofte tenderer mod at bekræfte, hvad en person eller en ting er, og hvad den er, universelt betragtet, for en hvilken som helst person og således objektivt set. Det er, som Kafka tydeligt så det, en næsten guddommelig diskurs, der tildeler enhver en identitet. For det andet administrerer den gennem direktiver, ordrer, forskrifter etc. og fortæller, hvad folk skal gøre, afhængig af, hvad de er. For det tredje fortæller den i autoriserede optegnelser, såsom politirapporter, hvad folk i virkeligheden har gjort. I hvert tilfælde påtvinger den et synspunkt, institutionens, især gennem spørgeskemaer, officielle formularer etc. Dette synspunkt opstilles som et legitimt synspunkt, dvs. som et synspunkt, enhver skal anerkende i det mindste inden for et givet samfunds grænser. Statens repræsentant er et opbevaringssted for fornuft: Officielle udnævnelser og eksamensbeviser har gerne en universel værdi på alle markeder. Den mest typiske effekt af denne 'raison d'Etat', statsfornuft, er kodifikationseffekten, som fungerer ved handlinger så simple som tildelingen af et diplom: En ekspert, læge, jurist el.lign. er en, der er udpeget til at producere et synspunkt, som overskrider det personlige synspunkt, i form af lægeerklæringer; certifikater, der udtrykker kompetence eller inkompetence; et synspunkt, som tildeler indehaveren af certifikatet universelt anerkendte rettigheder. Staten optræder på denne måde ligesom centralbanken, idet den garanterer alle certifikater. Man kan sige om staten med de termer Leibniz brugte om Gud, at den er det "geometriske locus for alle perspektiver". Det er derfor man må generalisere Webers berømte formel og i staten se indehaveren af monopolet på legitim symbolsk vold. Eller mere præcist: Staten er en dommer, endda en meget magtfuld dommer, i kampene om dette monopol.

Men i kampen om produktionen og påtvingelsen af en legitim vision om den sociale verden opnår indehaverne af den bureaukratiske autoritet aldrig et absolut monopol, ikke en gang, når de føjer videnskabens autoritet til deres bureaukratiske autoritet, som stats $\varnothing$ konomer gør det. Faktisk er der i et samfund altid konflikter mellem symbolske magter, som har til hensigt at påtvinge modparten deres vision om den legitime inddeling, dvs. konstrueringen af grupper. Symbolsk magt er i denne mening en magt til "verdensskaben". Verdensskaben består ifølge Nelson Goodman i at "adskille og genforene, ofte i den samme operation", i at udføre en dekomposition eller analyse og en komposition eller syntese, ofte ved brug af etiketter. Social klassifikation fungerer oftest, som det er 
tilfældet i arkaiske samfund, gennem dualistiske operationer (maskulin/ feminin, høj/lav, stærk/ svag), organiserer opfattelsen af den sociale verden og kan under særlige omstændigheder virkelig organisere verden selv.

Vi kan nu begynde at unders $\varnothing$ ge, under hvilke betingelser en symbolsk magt kan blive til en konstituerende magt, idet vi med John Dewey tager termens såvel filosofiske som politiske mening $\mathrm{i}$ betragtning. Dvs. en magt til at bevare eller ændre de objektive principper for forening eller adskillelse, ægteskab eller skilsmisse, association eller dissociation, som fungerer i den sociale verden; en magt til at bevare eller omforme nuværende klassifikationer vedrørende $k \varnothing n$, nation, region, alder og social status; en magt viderebragt af de ord, som bruges til at betegne eller beskrive individer, grupper eller institutioner.

For at forandre verden må man ændre måden, hvorpå verden skabes, dvs. visionen om verden og de praktiske operationer, hvor grupper produceres og reproduceres. Symbolsk magt, hvis mest eksemplariske form ses i magten til at producere grupper (allerede etablerede grupper, som må anerkendes, eller grupper, som stadig mangler at blive etableret, som det Marx'ske proletariat), er baseret på to betingelser. For det første må symbolsk magt, som enhver form for diskurs, der undviger noget, baseres på besiddelsen af symbolsk kapital. Magten til at påtvinge andre en vision, gammel eller ny, om social inddeling, afhænger af den sociale autoritet opnået i forudgående kampe. Symbolsk kapital er en anerkendelse, det er styrken tildelt dem, der har opnået tilstrækkelig anerkendelse til at være i en position, hvor de kan forlange yderligere anerkendelse: Sådan kan den konstituerende magt - magten til ved mobilisering at danne en ny gruppe, eller til at lade den eksistere ved prokuration, ved at tale på dens vegne, som en autoriseret talsmand - kun opnås ved afslutningen af en lang institutionaliseringsproces, for enden af hvilken der vælges en repræsentant, som fra gruppen modtager magten til at danne gruppen.

For det andet afhænger symbolsk effektivitet af, i hvilken grad den foreslåede vision er baseret på realiteter. Helt indlysende kan konstruktionen af grupper ikke være en konstruktion ex nihilo. Den har desto større chance for succes, jo mere den er funderet i virkeligheden, ergo som jeg har sagt i de objektive affiniteter mellem mennesker, som må bringes sammen. Teori-effekten er desto mere magtfuld, jo mere adækvat teorien er. Symbolsk magt er en magt til at skabe ting med ord. Det er kun hvis den er sand, dvs. adækvat med ting, at en beskrivelse kan skabe ting. I denne mening er symbolsk magt en magt til indvielse eller åbenbaring, en magt til at skjule eller åbenbare ting, som allerede er der. Betyder det, at den ikke gør noget? Ifølge Nelson Goodman begynder en konstellation i virkeligheden først at eksistere, når den er selekteret og beskrevet som sådan for dem, som er en del af den, og også for andre; en gruppe, en klasse, et køn, en region eller en nation begynder først at eksistere, når den skiller sig ud fra andre grupper gennem erkendelse og anerkendelse i overensstemmelse med et eller andet princip.

Det er således, håber jeg, lettere at forstå, hvad der er på spil i kampen om eksistensen eller ikkeeksistensen af klasser. Kampen om klassifikationer er en fundamental del af klassekampen. Magten til at påtvinge en vision om inddelingerne, dvs. magten til at synliggøre og eksplicitere sociale inddelinger, som er implicitte, er den politiske magt par excellence: Det er magten til at danne grupper, til at manipulere samfundets objektive strukturer. Ligesom det er tilfældet med konstellationer, skaber den udøvende magt betegnelser og nomineringer i en oprettet, konstitueret form, (dvs. som et 'korpo', en corporatio, som de middelalderlige kanonister, studeret af Hermann Kantorowicz, sagde), det der ind til da kun eksisterede som en collectio personarum plurium., en samling af mange personer, en rent additiv gruppe af individer, der blot var placeret side om side.

Hvis vi genkalder os det hovedproblem, jeg har fors $\varnothing$ gt at forklare i dag, der handler om, hvordan man kan skabe ting (dvs. grupper) med ord, konfronteres vi med et sidste spørgsmål, spørgsmålet om mysteriet om ministeriet, som kanonisterne yndede at formulere det: Hvordan bliver talsmanden udstyret med fuldmagt til at handle og tale på vegne af gruppen, som han producerer gennem 
magien i sloganet, feltråbet eller kommandoen, og ved sin blotte eksistens som en inkarnation af gruppen? Som kongen i de arkaiske samfund, rex, der ifølge Emile Benveniste har til opgave at regere fines og at regere sacra, at opspore og statuere grænserne mellem grupper, og derved få dem til at eksistere som sådanne, er lederen af en fagforening eller et politisk parti, tjenestemanden eller den statsautoriserede ekspert, en af så mange personificeringer af en social fiktion, som de giver eksistens i og med selve deres væren, og fra hvilken de til gengæld modtager deres magt. Talsmanden er stedfortræder for gruppen, som udelukkende eksisterer gennem denne bemyndigelse, og som handler og taler gennem ham. Han er personificeringen af gruppen. Som kanonisterne siger: Status, positionen, er magistratus, magistraten, som optager den; eller som Louis XIV sagde: "L'État, c' est moi", "Staten, det er mig"; eller igen, med Robespierres ord, "Je suis le peuple", "Jeg er folket". Klassen (eller folket, eller nationen, eller en hvilken som helst anden social realitet, som ikke kan begribes på nogen anden måde) eksisterer, hvis der findes mennesker, der udgør klassen ved det blotte faktum, at de kan tale offentligt, officielt på klassens vegne - og at de bliver anerkendt herfor og får retten hertil af deres folk. Selve folket betragter herved sig selv som medlemmer af klassen, folket eller nationen, eller af en hvilken som helst anden social virkelighed, og betragter den konstruktion som en realitet.

Jeg håber, at jeg inden for grænserne af min sproglige kapacitet, har overbevist jer om, at kompleksiteten ligger $\mathrm{i}$ den sociale virkelighed og ikke i det noget dekadente $\emptyset$ nske om at sige komplicerede ting. "Det enkle", plejede Gaston Bachelard at sige, "er aldrig andet end det forenklede". Han demonstrerede, at videnskab aldrig har gjort fremskridt, undtagen ved at sætte spørgsmålstegn ved enkle ideer. Et tilsvarende spørgsmål, forekommer det mig, trænger til at blive stillet til de sociale videnskaber på grund af det faktum - blandt alle dem jeg har nævnt - at vi for let $\emptyset$ nsker at tilfredsstille os selv med de indlysende billeder, vi udleder af vores ' sund fornuft-erfaring' eller vores fortrolighed med en videnskabelig tradition.

\section{Referencer}

Bourdieu, P. (1990). Social space and symbolic power. I: In other Words, essays towards a Reflexive Sociology. Cambridge: Polity Press.

Bourdieu, P. (1988). The Categories of Professorial Judgement. I: Homo Academicus. Cambridge: Polity Press.

Bourdieu, P. (1979). La Distinction. Critique sociale du jugement. Paris: Éditions de Minuit.

Bourdieu, P. \& Passeron, J-C. (1970). La reproduction. Éléments pour une théorie du système d'enseignement. Paris: Éditions de Minuit.

Bourdieu, P., Passeron, J-C. \& de Saint Martin, M. (red.)(1965). Rapport pédagogique et communication. Paris: Mouton.

Callewaert, S., Munk, M., Nørholm, M. og Petersen K.A. (red.)(1994-2008): Pierre Bourdieu. Centrale tekster inden for sociologi og kulturteori. København: Akademisk Forlag/Frydenlund.

Kafka, F. (1953). The Trial. Harmondsworth: Penguin Books.

Schutz, A. (1973). Collected Papers. Vol. I. The Problem of Social Reality. The Hague: Martinus Nijhoff. Thompson, E.P. (1963). The Making af the English Working Class. Toronto: Doubleday. 